\title{
WIELKA ŁACIŃSKA FORMUŁA ANATEMATYZMU - ODRZUCENIA MANICHEIZMU
}

\begin{abstract}
WSTĘP
Łaciński tekst, opublikowany jako Prosperi Anathematismi, który wydał Jean-Paul Migne (PL 65, 23-26), a także Josepchus Zycha (CSEL 25/2, Pragae - Vindobonae - Lipsiae 1892, 980-982, zawiera zdania (1-9 i 18-19) odpowiadające tym, które sa zamieszczone w tzw. Commonitorium Augustini (1-8 i 9-10). Tekst datowany jest na rok 526. Myśl teologiczna formuły nawiązuje do teologii Augustyna, co potwierdza autorytet tego Ojca Kościoła w walce z manicheizmem w łacińskiej strefie językowej. Mogła także powstać w środowisku zwolenników teologii św. Augustyna. Formuła ta rzuca światło na to, jak przedstawiał się manicheizm w łacińskiej części Cesarstwa w V i VI wieku. Wiadomo, że manichejczycy w każdym środowisku religijnym dostosowali terminologię i argumentację do warunków lokalnych. Anatematyzmy ujmują stronę doktrynalną manicheizmu, brak w nich natomiast potępienia obyczajów i etyki manichejskiej. Wydaje się więc, że zostały dostosowane do pozytywnego wyznania wiary w Kościele.

Formuła ta była używana wobec wszystkich, których posądzano o „manichejski” dualizm, a więc prawdopodobnie w średniowieczu także wobec katarów. Główne stwierdzenia (capitula) św. Augustyna, należało wypowiedzieć publicznie i głośno oraz własnoręcznie podpisać (dokument), jeśli zaistniało podejrzenie wyznawania poglądów manichejskich.

Formuły wyrzekania się błędów zostały rozwinięte przede wszystkim na Wschodzie, w części greckiej ${ }^{1}$. W odniesieniu zaś do formuł łacińskich wydaje się, że zagadnienie to nie zostało dostatecznie opracowane ${ }^{2}$. Zdaniem Wolfganga W. Kleina tzw. „wyrzekanie się herezji” stanowiło osobną formę literacką.
\end{abstract}

1 Według W.W. Kleina (Die Argumentation in den griechisch-christlichen Antimanichaica, Wiesbaden 1991, 15), krótkie formuły pojawiły się po roku 450, długie ok. roku 900; por. S.N.C. Lieu, Manichaeism in Mesopotamia and the Roman East, Köln 1994, 208-210.

${ }^{2}$ Greckie formuly, por. S.N.C. Lieu, An Early Byzantine Formula for the Renunciation of Manichaeism - The Capita VII contra Manichaeos of Zacharias of Mitylene. Introduction, Text, Translation and Commentary, JbAC 26 (1983) 152-218; wcześniej opracował je: G. Ficker, Eine Sammlung von Abschwörungsformeln, ZKG 27 (1906) fasc. 1, 443-464.

${ }^{3}$ Por. W.W. Klein, Abschwörungsformeln, w: tenże, Die Argumentation in den griechischchristlichen Antimanichaica, s. 16-17. 


\section{WYDANIA TEKSTU}

J.P. Migne: $\quad$ Paris 1847, PL 65, 23-26.

J. Zycha: $\quad$ Pragae - Vindobonae - Lipsiae 1892, CSEL 25/2, 980-982.

A. Adam: Berlin 1969², Texte zum Manichäismus, p. 62, s. 90-93.

\section{BIBLIOGRAFIA}

G. Ficker, Eine Sammlung von Abschwörungsformeln, ZKG 27 (1906) fasc. 1, 443464; V. Arnold-Döben, Die Bildersprache des Manichäismus (Als Manuskript veröffentlicht), Köln 1978; S.N.C. Lieu, An Early Byzantine Formula for the Renunciation of Manichaeism - The Capita VII contra Manichaeos of Zacharias of Mitylene. Introduction, Text, Translation and Commentary, JbAC 26 (1983) 152-218; W. Myszor, Wstęp, w: Św. Augustyn, Pisma przeciw manichejczykom, thum. J. Sulowski, PSP 54, Warszawa 1990, 5-32; W.W. Klein, Die Argumentation in den griechisch-christlichen Antimanichaica, Wiesbaden 1991; S.N.C. Lieu, Manichaeism in Mesopotamia and the Roman East, Köln 1994; J. Tubach, Nochmals Addas-Adeimantos, ZPE 106 (1996) 170-174; W. Myszor, Stwórca świata i szatan, w: tenże, Gnostycyzm i teologia Ireneusza z Lyonu, Katowice $2010=$ SACh SN 11 (2010) 167-179, spec. s. 106-114: Chrystologia gnostyków: podstawowe problemy.

\section{PRZEKŁAD*}

1. Kto wierzy, że istnieją dwie przeciwstawne zasady bytu (diversa principia) w dwu naturach, a mianowicie jedna w postaci Boga, który jest dobry i innego złego bytu, którego Bóg nie stworzył, a który ma swoich władców (principes) i własne złe istoty, których Bóg nie stworzył, niech będzie wyklęty (anathema sit).

2. Kto wierzy, że owe dwie natury prowadziły między sobą wojnę i że część natury bożej w tej wojnie z władcami ciemności i wszystkimi pokoleniami, które należą do owej złej natury, została zmieszana (z nimi) i została przez nich opanowana, uwięziona, uciskana i zanieczyszczona, a więc jeśli wierząc $\mathrm{w}$ to sprawia, że natura boża jest zmienna i że jest podatna na zanieczyszczenie, niech będzie wyklęty.

3. Kto wierzy, że uwięziona i zanieczyszczona część boska jest uwięziona wśród demonów i zatrzymana we wszystkich żyjących istotach i pokoleniach potomków, ale dzięki pokarmom przyjmowanym przez manichejczyków zostaje uwolniona i oczyszczona, a także, że w ten sposób wierzy, że owa zanieczyszczona cząstka boska znajduje się w ogórkach, melonach,

* Tłumaczenie z języka łacińskiego wg wydania: A. Adam, Texte zum Manichäismus, Berlin 1969 , p. 62 , s. $90-93$. 
rzodkiewkach, w czosnku, oraz we wszystkich możliwych całkowicie bezwartościowych warzywach, oraz kto wierzy, że jeśli wybrani (electi) spośród manichejczyków to zjedzą, to przychodzą (tej boskiej cząstce) z pomocą, niech będzie wyklęty.

4. Kto wierzy, że pierwszy człowiek, który został nazwany Adamem, nie został stworzony przez Boga, lecz że pochodzi od mocy ciemności i to w ten sposób, że cząstka boskości, która w jego członkach została uwięziona, występuje na ziemi w liczbie większej i bogatszej, niech będzie wyklęty.

5. Kto wierzy, jakoby człowiek został stworzony takim sposobem, że władcy ciemności, męskiego i żeńskiego rodzaju, spali razem i owoce swojego ciała przekazali najwyższemu władcy ciemności, ten zaś zjadł je wszystkie i gdy współżył ze swoją małżonką spłodził z nią Atlasa, którego bluźnierczo nazywają ojcem Adama, przy czym związał z nim wielką część pochodzącą od Boga, która była złączona z wszystkimi cielesnymi owocami władców ciemności, które ci władcy dali mu do zjedzenia (kto tak wierzy) niech będzie wyklęty.

6. Kto wierzy, że władcy ciemności są związani z niebem jak ciała niebieskie i że jakoby mają w sobie w czas trwogi i lęku siłę życiową, która jest z nimi związana, to jest cząstkę boskości, oraz że będą ze swoich członków wyzwoleni, gdy błogosławiony ojciec (beatus pater), który ma świetliste statki, czyli słońce i księżyc jako mieszkania i miejsca pobytu, [a] swoje moce zamieni na piękne kobiety, przedstawi mężczyznom, władcom ciemności jako stworzenia godne pożądania, zaś pięknych mężczyzn, przedstawi władczyniom ciemności jako stworzenia godne pożądania po to, aby siłę życiową przez moc pożądania, to jest cząstkę boskości z nich wyzwolić i uwolnić z ich członków, aby mogła być oczyszczona, [kto w to wierzy] niech będzie wyklęty.

7. Kto wierzy, że cząstka boskości, która przez zmieszania z ludem ciemności nie zostaje uwolniona i oczyszczona, jest potępiona i na zawsze uwięziona w straszliwej zbitej masie kulistej (,globus”), w której uwięził ją lud ciemności, [kto tak wierzy] niech będzie wyklęty.

8. Kto wierzy, że prawo, które nadał Mojżesz, nie jest tym, które dał jeden prawdziwy Bóg i prorocy, które było w ludzie Izraelskim i zawarte jest w kanonie Bożych pism Kościoła Katolickiego, [kto wierzy] jakoby prawo nie pochodziło z ducha dobrego i prawdziwego Boga, niech będzie wyklęty.

9. Kto wierzy, że Syn Boży, nasz Pan Jezus Chrystus, nie miał prawdziwego ciała, że nie pochodził z rodu Dawida, zrodzony z dziewicy Maryi, że nie miał rzeczywistego ciała, a także, że nie cierpiał ponosząc prawdziwą śmierć, że nie powstał z martwych, lecz pozostał tylko samym duchem bez ciała, ale miał ciało pozorne, gdy chciał się objawić, żeby mu przypisywano ciało (ut caro putaretur), choć go nie miał, i kto w ten sposób zaprzecza Ewangelii, gdzie czytamy, że sam Pan powiedział: „Popatrzcie na moje 
ręce i moje nogi, dotknijcie je i zobaczcie: duch nie ma kości i nie jest ciałem, ale wy widzicie, że ja mam" (Łk 24,39), kto więc uznaje, że Chrystus jest Bogiem, ale zaprzecza, że rzeczywiście i całkowicie jest człowiekiem, niech będzie wyklęty.

10. Ktokolwiek wierzy, że nadejście Ducha Świętego, które Pan zapowiedział w ewangelii, że zstąpi na apostołów, nastąpiło nie wtedy, gdy wkrótce po zmartwychwstaniu Pana wypełniło się to w czasie Zielonych Świąt, lecz wierzy, że stało się to po wielu latach na Manim, albo na jego uczniu Adimancie, ten niech będzie wyklęty.

11. Kto zaprzecza temu, że ciało, które mamy na sobie, to znaczy ludzkie ciało, zmartwychwstanie, niech będzie wyklęty.

12. Kto wierzy, że ludzkie dusze będą ponownie wchodzić w inne ciała lub istoty żywe, niech będzie wyklęty.

13. Ktokolwiek twierdzi, że słońce i księżyc są niebiańskimi okrętami dla przewiezienia dusz lub boskich istot, a tym bytom właśnie albo temu widzialnemu światłu przypisuje jakąkolwiek boskość i wierzy, że nie zostały stworzone jak pozostałe stworzenia Pana niebios i ziemi dla służby człowieka, niech będzie wyklęty.

14. Kto wierzy, że wszelkie ciało czteronożnych zwierząt, a także węży, ptaków, ryb i odpowiednio wszystko istot żyjących, które są na ziemi, nie zostało stworzone przez prawdziwego Boga, lecz przez księcia ciemności, niech będzie wyklęty.

15. Kto nie odrzuci wyznania wiary albo modlitwy manichejczyków, lecz czci je i chciałby je zapamiętać albo wymawiać, niech będzie wyklęty.

16. Kto wierzy, że ludzkie dusze pochodzą z istoty Boga, a ciała ludzkie pochodzą lub zostały stworzone przez księcia ciemności, niech będzie wyklęty.

17. Kto wierzy, że diabeł nie został stworzony przez Boga jako dobry anioł i że z własnej woli na skutek pychy upadł i stał się diabłem i kto twierdzi, że nie został stworzony razem z pozostałymi aniołami przez Boga, lecz że istnieje zawsze jako współwieczny z Bogiem, niech będzie wyklęty.

18. Kto twierdzi, że Mani, odpowiednio Manicheusz, który z powodu wszystkich swoich pism zasłużył sobie, aby został odrzucony i przeklęty i który nadto głosił kazania i nauczał, że posiadł Ducha Świętego, Parakleta, to te wszystkie dzieła wskazują że nie mógł mieć ducha prawdy, lecz mógł nauczać $\mathrm{z}$ ducha fałszu, niech będzie wyklęty.

19. Niech będzie wyklęty sam Mani, odpowiednio Manicheusz, który wszystkie te bezbożności wskazane wyżej, a także inne świętokradztwa, a także gdy nauczał i napisał godne potępienia opowieści i usiłował przekonać, że te głupstwa godne są wiarogodności, starając się także o to na podstawie duchów uwodzenia a także nauk zakłamanych demonów. 
20. Niech będzie wyklęty Adimant i wszyscy jego uczniowie i zwolennicy; a także jak już powiedziano, ten, kto wierzy, że i na niego przyszedł Duch Święty, także niech będzie wyklęty.

21. Przeklęci niech będą także wszyscy twórcy pism i wspomnianych wyżej nauk, ich nauki i odpowiednio ich prawo, wszystkie tajemne nauki i wypowiedzi, które sprzeczne są z wiarą katolicką, ich świętokradztwa i wszystkie ich pisma, które nie zostały wprowadzone do kanonu Kościoła, a więc każdy, kto nie przyjął słusznej wiary.

\section{KOMENTARZ}

Ad 1. Dwie natury: por. Augustinus, Contra Felicem II 2-7, ed. J. Zycha, CSEL 25/2, 829-835, thum. J. Sulowski: Św. Augustyn, Przeciw Feliksowi, w: Św. Augustyn, Pisma przeciw manichejczykom, PSP 54, Warszawa 1990, 230-233.

Ad 2. Walka natur: por. Augustinus, Contra Felicem I 19-20, CSEL 25/2, 824827, PSP 54, 227-228.

Ad 3. Założenia manichejskiej etyki i przepisów pokarmowych: por. Augustinus, Contra Faustum XXXI 3-4, ed. J. Zycha, CSEL 25/1, Pragae - Vindobonae - Lipsiae 1891, 758-760, thum. J. Sulowski: Św. Augustyn, Przeciw Faustusowi, w: Św. Augustyn, Przeciw Faustusowi, Przeciw Sekundynowi, PSP 56, Warszawa 1991, 124-126. Anatematyzm wyraźnie zaznacza, że przepisy pokarmowe ściśle obowiązywały tylko grupę „wybranych” czyli electi, gdyż zgodnie z ich doktryną tylko oni mogli dzięki swojej doskonałości „naturalnej” uwalniać cząstki światłości, „,boskości”, z materialnych pokarmów. Cząstki światłości (boskie) według manichejczyków znajdowały się w niektórych pokarmach (zielonych). Doskonali przez tego rodzaju dietę uwalniali je od uwikłania z cząstkami ciemności. Ten manichejski zwyczaj był bardziej widoczny w życiu codziennym niż w poglądach religijnych. Łatwiej zresztą można go było także zwalczyć, nie tylko przez anatematyzm, ale po prostu przez spożycie odpowiednich (,katolickich”) pokarmów.

Ad 4. Powstanie Adama, że został stworzony przez ,władców ciemności” nawiązuje do dawnego mitu gnostyckiego, wyraźnie opisanego w Apokryfie Jana (11, thum. W. Myszor, w: Biblioteka z Nag Hammadi. Kodeksy I i II, SACh SN 7, Katowice 2008, 176-178) i Hipostazie archontów (3-4, tłum. W. Myszor, SACh SN 7, 300-301).

Ad 5. Najwięcej o tym gnostycko-manichejskim micie pisze Augustyn (Contra Felicem II 7, CSEL 25/2, 834-835, PSP 54, 234-235).

Ad 6. Mit statków niebieskich świateł (słońca i księżyca), por. Augustinus, Contra Faustum XX 6-9, CSEL 25/1, 540-546, tłum. J. Sulowski: Augustyn, Przeciwko Faustusowi, PSP 55, Warszawa 1991, 218-223; zob. także V. Arnold-Döben, Die Bildersprache des Manichäismus (Als Manuskript veröffentlicht), Köln 1978, 168-169; Augustinus, Contra Felicem II 7, CSEL 25/2, 834-835, PSP 54, 234, nota 61. 
Ad 7. Łac. globus tenebrarum (gr. $\beta \hat{\omega} \lambda \mathrm{o} \varsigma$ ), w relacjach Augustyna: Contra Adimantum 7, 1, ed. J. Zycha, CSEL 25/1, 127 (genti tenebrarum), tłum. J. Sulowski, PSP 54, 162 i nota 52; Contra Felicem II 8, CSEL 25/2, 836 (gens enim tenebrarum), PSP 54,235 i nota 65.

Ad 8. Według manichejczyków prawo i prorocy Starego Testamentu zostali ustanowieni przez stwórcę świata, demiurga. W tym kontynuowali myśl gnostycką, por. W. Myszor, Stwórca świata i szatan, w: tenże, Gnostycyzm i teologia Ireneusza z Lyonu, Katowice $2010=$ SACh SN 11 (2010) 167-179.

Ad. 9. Anatematyzm przeciwko manichejskiej chrystologii. W ujęciu manichejskim Chrystus miał pozorne ciało, dlatego nie poniósł śmierci na krzyżu. Teza manichejska wyraźnie sprzeczna z katolickim wyznaniem wiary. Gnostycka chrystologia, do której manichejczycy nawiązali, była bardziej skomplikowana; por. W. Myszor, Chrystologia gnostyków: podstawowe problemy, SACh SN 11 (2010) 106-114. W tym anatematyzmie znajdziemy aluzję do wyznania manichejskiego: „Chrystus jest Bogiem"; tak być może wyznawali manichejczycy swą wiarę i w ten sposób wśród niezbyt dobrze zorientowanych chrześcijan unikali podejrzenia o herezję.

Ad 10. Autorytet Maniego był m.in. umocniony tym, że według manichejskiej doktryny Duch Święty - Paraklet zstąpił na Maniego. Mniej znany jest pogląd, że zstapił On także na Adimanta, jednego z uczniów Maniego. Augustyn wspominał o takich roszczeniach manichejczyków w piśmie List który nazywaja podstawowym (Contra epistulam fundamenti 6-7, ed. J. Zycha, CSEL 25/1, 199-201) i Przeciw Feliksowi (Contra Felicem I 9-10, CSEL 25/2, 811-812, PSP 54, 216). Do innego manichejczyka - Adimanta, anatematyzm wraca w p. 20.

Ad 11. Odrzucenie katolickiej nauki o zmartwychwstaniu ciała przez manichejczyków w świetle innych manichejskich twierdzeń jest zrozumiałe. Natomiast sformułowanie w katolickim credo ,zmartwychwstanie ciała” ma wyraz antymanichejski.

Ad 12. Manichejska nauka o wędrówce dusz: Augustinus, Contra Faustum XX 20, CSEL 25/1, 561, PSP 55, 235.

Ad 13. Anatematyzm nawiązuje do nr 6 przez motyw statków świetlistych słońca i księżyca.

Ad 14. Manichejski zakaz spożywania mięsa był uzasadniony przez pogląd, który anatematyzm odrzuca: mięso (ciało) pochodzi od władców ciemności (w gnostycyzmie: archontów). Tego rodzaju posty obowiązywały przede wszystkim „wybranych” (electi) wśród manichejczyków. Po tych zwyczajach można było łatwo odróżnić manichejczyków od chrześcijan.

Ad 15. Anatematyzm potwierdza, że manichejczycy formułowali własne wyznanie wiary i mieli własne modlitwy a więc i liturgię. Potwierdzają to oryginalne pisma manichejskie; na ten temat por. W. Myszor, Wstęp, w: PSP 54, 16-21 (Pisma manichejskie w Afryce Pólnocnej).

Ad 16. Manichejskie ujęcie pochodzenia duszy polega na tym, że dusza ,pochodzi od Boga" jako cząstka boskości. Ta boska dusza zostaje uwięziona w ciele, które 
pochodzi o „władców ciemności”. Augustyn przedstawił ten manichejski dualizm antropologiczny, jak się wydaje, w niezbyt trafnym ujęciu nauki o dwu duszach w człowieku: por. Augustinus, De duabus animabus, ed. J. Zycha, CSEL 25/1, 51-80, thum. J. Sulowski: Św. Augustyn, O dwóch duszach, PSP 54, 67-88.

Ad 17. Por. Augustinus, Contra Felicem II 2, CSEL 25/2, 829-830, PSP 54, 230; II 6-7, CSEL 25/2, 833-834, PSP 54, 233; II 10-11, CSEL 25/2, 839, PSP 54, 238; II 16, CSEL 25/2, 845, PSP 54, 243.

Ad 18. Autorytet Maniego w nauczaniu i pismach jego zwolennicy odnosili do Ducha Świętego (Parakleta), por. anatematyzm 10.

Ad 19. Tekst potwierdza istnienie łacińskiej wersji imienia Maniego, ,Manichaeus”. Odrzuca naukę Maniego wzmocnionym argumentem, że pochodzi ona od demonów.

Ad 20. Adimantus jeden z trzech najwierniejszych uczniów Maniego (Addas). Według Augustyna napisał dzieło Przeciwko Mojżeszowi i innym prorokom. Augustyn zwalczał jego poglądy w Przeciw Adimantowi (Contra Adimantum, CSEL 25/1, 115-190, PSP 54, 153-207) z roku 394. Adimantos (Addas/Adeimantus) należał do najbardziej poczytnych autorów manichejskich na Zachodzie ${ }^{4}$.

Ad 21. Ostatni anatematyzm przezornie nie wymienia tytułów łacińskich pism manichejczyków, potępia je zresztą w sposób ogólny (,wszystkie pisma, które nie zostały wprowadzone do kanonu Kościoła”).

Z języka łacińskiego przełożył, wstępem i komentarzem opatrzył ks. Wincenty Myszor**

${ }^{4}$ Por. J. Tubach, Nochmals Addas-Adeimantos, ZPE 106 (1996) 170-174.

${ }^{* *}$ Ks. prof. dr hab. Wincenty Myszor - emerytowany pracownik Wydziału Teologicznego na Uniwersytecie Śląskim w Katowicach; e-mail: wincenty2myszor@onet.pl. 
